\title{
Overview of the Human Carcinogenicity Risk Assessment of Metallic Chromium and Trivalent Chromium
}

\author{
M Nurminen
}

\begin{abstract}
Citation
M Nurminen. Overview of the Human Carcinogenicity Risk Assessment of Metallic Chromium and Trivalent Chromium. The Internet Journal of Epidemiology. 2005 Volume 2 Number 1.
\end{abstract}

DOI: $\underline{10.5580 / 1082}$

\begin{abstract}
This paper reviews evaluations and studies on the carcinogenicity in humans of metallic chromium and trivalent chromium as well as leather tanning and chromium plating and processing. The evaluations of the potential carcinogenicity of metallic chromium and trivalent chromium by international and national organizations and individual scientists are unanimous in that the evidence of carcinogenicity is inadequate in humans. For some occupational sources of chromium exposure (e.g. ferrochrome industry and manufacture of chrome pigments) and for some occupations (e.g. leather tanners, painters and chrome platers) there are increased risks, but in most epidemiologic studies the available data do not permit discrimination between simultaneous exposure to trivalent and hexavalent chromium. Although the chromium compound that increases the risk of lung cancer and sinonasal cancer has yet to be identified, there is general agreement that hexavalent species are responsible for these diseases, and that the trivalent and metallic species are not. For cancers other than those of the lungs and sinonasal cavity, no consistent pattern of cancer risk has been demonstrated in workers exposed to chromium compounds.
\end{abstract}

\section{INTRODUCTION}

The naturally occurring mineral chromite contains chromic oxide (a trivalent chromium compound). Chromium metal (chromium $(0)$ is present in ferrochromium used in stainless steel manufacture and other alloy production. In ferrochromium operations, trivalent (insoluble) chromium (chromium(III)) predominates, but hexavalent (soluble) chromium (chromium(VI)) may also occur at low levels. In chromate production, exposure to chromium(III) and chromium(VI) can occur in mixing and roasting operations, while exposure to chromium(VI) is found in the treatment of end products, e.g., in filtering and shipping areas. Chromium compounds are also used for chrome plating, the manufacture of dyes and pigments, and in wood preservation. Leather tanning operations involve only chromium(III) exposure with the exception of the two-bath process in which chromium(VI) is used. The two-bath method is still used for some varieties of leather tanning but has generally been replaced by the one-bath tanning.

Several international and national agencies 12345 have evaluated the carcinogenicity of chromium compounds on the basis of the combined results of epidemiologic studies, carcinogenicity studies in experimental animals, and various types of other relevant data. In the next four sections, I review summaries of the evaluations on carcinogenicity in humans with particular reference to metallic chromium, chromium(0)), and trivalent chromium (chromium acetate, chromium chloride, chromium oxide, chromite ore, chromium sulphate), chromium(III), as well as leather tanning, chromium plating and processing. This is followed by an evaluation of the available evidence of chromiuminduced carcinogenecity from recent epidemiologic studies. Possible carcinogenic mechanisms are briefly cited. The final section procides an overall assessment.

\section{SUMMARY OF DATA REPORTED AND THE EVALUATION BY THE INTERNATIONAL AGENCY FOR RESEARCH ON CANCER (IARC)}

The information presented in this section is excerpted from the IARC monographs that concern chromium, ${ }_{1}$ paint manufacture and painting, ${ }_{6}$ and the supplement on leather tanning and processing. 7 The IARC Monographs series publishes authoritative assessments of carcinogenic risks by Working Groups of international experts.

\section{CARCINOGENICITY DATA ON METALLIC}




\section{CHROMIUM AND TRIVALENT CHROMIUM COMPOUNDS}

Epidemiological studies carried out in the Federal Republic of Germany, ${ }_{8}$ Italy, ${ }_{9}$ Japan, ${ }_{10}$ the UK, ${ }_{11}$ and the USA, ${ }_{12}$ of workers in the chromate industry have consistently shown excess risks for lung cancer. The workers in this industry may be exposed to a variety of forms of chromium, including chromium(III) and chromium(VI) compounds.

Studies carried out in the production of chromate pigments have also consistently shown excess risks for lung cancer. Workers in this industry are exposed to chromates, not only in the pigments themselves but also from soluble

chromium(VI) compounds in the raw materials used in their production. Excess risk for lung cancer has been clearly established in facilities where zinc chromate was produced, although other chromium pigments were also generally made in these plants. A small study on workers producing lead chromate pigments showed no overall excess risk for lung cancer. No data were available on risk associated with xposure to strontium chromate or to other specific chromate pigments.

In three reports, from Norway, ${ }_{13}$ Sweden, ${ }_{14}$ and the former USSR, ${ }_{15}$ in which ferrochromium workers were studied, the overall results with regard to lung cancer were inconclusive. The major exposure in this industry is to chromium(III) compounds and to metallic chromium, although exposure to chromium(VI) may also occur.

Cases of sinonasal cancer were reported in epidemiological studies of primary chromate production workers with exposure to chromium(VI) and chromium(III) in Japan, 10 the $\mathrm{UK}_{16}$, and the US, ${ }_{17}$ of chromate pigment (exposure to chromium(III) and chromium(VI)) production workers in Norway, ${ }_{18}$ and of chromium platers (exposure to chromium(VI)) in the UK, ${ }_{19}$ and the US, ${ }_{20}$ indicating a pattern of excess risk for these rare tumors.

For cancers other than of the lung and sinonasal cavity, no consistent pattern of cancer risk has been shown among workers exposed to chromium compounds. No epidemiological study has addressed the risk of cancer from exposure to metallic chromium alone.

The summary evaluation by the IARC was that there is inadequate evidence in humans for the carcinogenicity of metallic chromium and of chromium(III) compounds.

\section{CARCINOGENICITY DATA ON LEATHER TANNING AND PROCESSING}

Early studies of cancer risk possibly associated with leather industries provide little information specifically related to workers in tanneries. There was no evidence to suggest an association between leather tanning (mostly involving exposure to chromium(III)) and nasal cancer. ${ }_{21}$

Following the observation of an increased risk of nasal cancer among boot and shoe manufacturers, possibly associated with exposure to dust from leather tanned by a particular process, ${ }_{22}$ a study was designed to examine the possible cancer risk carried by different methods of leather tanning. The mortality experience of two groups of men working in tanneries in 1939 was compared to that of the population of England and Wales, and for no cause of death was a statistically significant increase above expectation found. 23

In a Swedish study, ${ }_{24}$ a slight increase in mortality from stomach cancer and a three-fold, significantly increased risk for cancer of the pancreas were found to be associated with the occupational titles 'tanners' and 'tannery workers'.

Tannery work involved exposure to chromium (chromium(III) and chromium(VI)) and, probably, to chlorophenols; smoking was an unlikely explanation for the findings, but the contribution of various dietary habits could not be ruled out. Suggestions of increased risks for intestinal cancer and lung cancer and for cancer of the tonsils were imputed by a mortality study of workers employed in a tannery plant using chromium salts and synthetic tannins. 25 An association between lung cancer and tannin was also suggested by a study of incident cases in the UK. ${ }_{26} \mathrm{~A}$ statistically significant association was also found in a study of cancer deaths among shoe and leather workers in the USA; ${ }_{27}$ chromium and arsenic were mentioned as possibly contributing to the excess of lung cancer. Significantly increased lung cancer mortality was also found among a group of fur tanners in the USA, who had probably been exposed to chrome (hexavalent) tanning agents. ${ }_{28}$ Note that hexavalent chromium compounds have no tanning properties and that chromium tanning salts contain trivalent compounds. Historically, most (or all) tanneries imported hexavalent chromium salts, typically sodium dichromate, for conversion to trivalent chromium tanning salts.

In a study of bladder cancer and occupation, a 1.5-fold excess risk (statistically nonsignificant) was found for leather tanners. ${ }_{21}$ No significant excess of bladder cancer 
was found in another study of tanners in the UK. ${ }_{29}$ In two of three areas in which a collaborative study of environmental risk factors for bladder cancer was conducted, a significant association with employment in 'leather' was found; the term 'leather' comprised the leather or tanning industry, the manufacture of leather goods, or shoemaking. ${ }_{30}$ In a cohort of 1630 leather tanners in Sweden, a 2-fold excess of kidney cancer was observed. ${ }_{31}$ This association was not supported by another study. 22

\section{CARCINOGENICITY DATA ON PAINT MANUFACTURE AND PAINTING}

Dye makers' work involves exposure to chromium(III), and painters' work may involve exposure to chromium(III) or chromium(VI), or both species. Although there is sufficient evidence for the carcinogenicity of occupational exposure as a painter, specific exposure to chromium(III) has not been examined. Painters' work involves also exposure to multiple other potential carcinogenic agents.

\section{OVERALL EVALUATION BY IARC}

- Metallic chromium and chromium(III) compounds are not classifiable as to their carcinogenicity to humans (Group 3).

- Leather tanning and processing entail exposures that are not classifiable as to their carcinogenicity to humans (Group 3).

- Occupational exposure as a painter is carcinogenic (Group 1).

- Occupational exposure in paint manufacture is not classifiable as to its carcinogenicity (Group 3).

\section{SUMMARY OF DATA REPORTED AND EVALUATION BY THE UNITED STATES ENVIRONMENTAL PROTECTION AGENCY (US EPA)}

The information presented in this section is excerpted from the US EPA Integrated Information System Summary. 32

\section{WEIGH OF EVIDENCE CHARACTERIZATION}

The US EPA scientists' weight-of-evidence judgment of the likelihood that the chemical substance of interest is a human carcinogen is made only after a comprehensive review of chronic toxicity data by the US EPA scientists. The summaries represent a consensus reached in the review process.
Chromium has been declared a carcinogen by the US EPA. ${ }_{33}$ While there is little doubt about the carcinogenicity of hexavalent (soluble) chromium, the carcinogenicity of trivalent (insoluble) chromium remains contested. Applying the criteria for evaluating the overall weight of evidence for carcinogenicity to humans outlined in EPA's guidelines for carcinogen risk assessment, ${ }_{34}$ trivalent chromium was most appropriately designated to Group D Not classified as to its human carcinogenicity. Using the Proposed Guidelines for Carcinogen Risk Assessment, ${ }_{35}$ there were inadequate data to rule out the risk of cancer attributable to trivalent chromium in the reviewed studies. All studies included mixed exposures to both chromium(III) and chromium(VI). This coexposure precluded the determination of whether trivalent chromium is carcinogenic or not, because data on exposure to chromium(III) alone were not available.

\section{EVALUATION BY THE UNITED STATES NATIONAL TOXICOLOGY PROGRAM (US NTP)}

Concurring with the evaluation of the IARC, the US National Toxicology Program Report on Carcinogenesis 36 recognizes that hexavalent chromium compounds (calcium chromate, chromium trioxide, lead chromate, strontium chromate, and zinc chromate) are known to be human carcinogens based on sufficient evidence of human carcinogenicity data. The US NTP Report documents that an increased incidence of lung cancer has been observed among workers in both the chromate-pigment manufacturing and bichromate-producing industry. A range of roasted chromite ores (chromium(III) or (VI)), often described as mixed chromium dust, and other residue materials are encountered in the early stages of bichromate production. There is evidence of a similar risk among chromium platers and chromium-alloy workers. An excess of respiratory cancer has usually been found for chromate-pigment makers and users. Chromium pigments can contain either trivalent or hexavalent chromium; the latter compounds commonly include zinc, lead, or strontium chromate. (Note that chromium pigments can be chromium(III) and chromium(VI) but chromate pigments are chromium(VI).) Chrome platers have also been found to have excess lung cancer. chromium(III) and chromium(VI) chemicals, but predominantly the latter, are used for chrome plating. However, a clear distinction between the relative carcinogenicity of chromium compounds of different oxidation states or solubilities has been difficult to make. Regarding the role of chromium(III), the Report ${ }_{36}$ does not include trivalent chromium in its list of substances known to be human carcinogens, or reasonably anticipated to be 
human carcinogens.

\section{CLASSIFICATION BY THE AMERICAN CONFERENCE OF GOVERNMENTAL HYGIENISTS (ACGIH)}

The ACGIH classification of the carcinogenicity of pertinence to human exposure to chromium is as follows: ${ }_{37}$

- Metal and chromium(III) A4: Not classifiable as a human carcinogen

- Water-soluble chromium (VI) A1: Confirmed human carcinogen

- Insoluble chromium (VI) compounds A1: Confirmed human carcinogen

\section{EVIDENCE FROM EPIDEMIOLOGIC STUDIES REVIEWS OF EPIDEMIOLOGIC EVIDENCE}

Lees ${ }_{38}$ reviewed epidemiologic evidence of chromium carcinogenicity. The association between employment in industries producing chromium (chromium(VI)) compounds from chromite (chromium(III)) ore and lung cancer has been well established in numerous studies. Although epidemiologic studies point to an increased risk with longterm employment, there is lack of quantitative data on the exposure-response relation. The association between exposure to certain chromium (chromium(VI)) pigments and chromium acids and lung cancer, although not as strong, is fairly well accepted. Lead and chromate pigments are the most widely used hexavalent pigments, although many others, including strontium chromate, barium chromate, and hydrated chromium oxide (the main trivalent pigment) are used. ${ }_{38}$ Note that chromium acid $\left(\mathrm{H}_{2} \mathrm{CrO}_{4}\right)$ contains hexavalent chromium, as do all chromate pigments, whereas chromium oxide $\left(\mathrm{Cr}_{2} \mathrm{O}_{3}\right)$ contains only trivalent chromium.

The data concerning emissions from stainless-steel manufacturing (exposure to chromium(0), chromium(III) and chromium(VI)) and disease are contradictory. Although individual studies have indicated excesses of gastrointestinal and occasionally other cancers in these industries, the results are inconsistent and not universally accepted.

Langård ${ }_{39}$ reviewed old and recent case reports and epidemiological studies among chromate workers to elucidate the importance of valency states and water solubility of chromium compounds for carcinogenic potency. He concluded that all chromium(VI) compounds should be considered carcinogenic among exposed populations, and that no evidence has been presented indicating that human exposure to chromium(III) is associated with increased cancer risk. Strong evidence has been presented that zinc chromate is a potent carcinogen, suggesting that calcium chromate may be a potent carcinogen. Evidence also indicates that water-soluble chromates in general may be more potent carcinogens than those with low solubility.

Hayes ${ }_{40}$ reviewed epidemiologic studies of the carcinogenicity of chromium. The following is an excerpt from the review. Elevated risks for lung cancer have been reported in the US, ${ }_{41}$ Japanese, ${ }_{42} \mathrm{UK},{ }_{43}$ and German ${ }_{8}$ chromate industries. Workers in the 'wet end' of the chromium chemical production process, where hexavalent compounds predominate, tended to have the highest risks. ${ }_{45}$ In one study, ${ }_{41}$ the risk increased with exposure to soluble (hexavalent) and insoluble (trivalent) chromium, but these exposures were highly correlated, and the risks of exposure to soluble and insoluble chromium could not be distinguished. An excess of respiratory cancer has been found among chromate pigment workers in Norway, ${ }_{18}$ the US, ${ }_{44}{ }_{45}$ Great Britain, ${ }_{46}$ France, ${ }_{47}$ Germany and the Netherlands, ${ }_{48}$ and Japan. ${ }_{49}$ Zinc chromate exposure was common to most of the workers studied and is a likely respiratory carcinogen in this industry. No excess respiratory cancers were noted among small subgroups exposed only to lead chromate. 50

In another review addressing specifically the occupational epidemiology of chromium chemicals and respiratory cancer, Hayes ${ }_{51}$ reports that strong and consistent associations have been found between employment in the primary chemical industry and the risk for respiratory cancer. Workers employed in chromate pigment production, and possibly spray painters of chromate pigment paints, appear to be at excess risk of respiratory cancer. Chrome platers may also be at excess risk, although the evidence is limited. Ferrochromium alloy workers have also shown an excess risk for respiratory cancer, although the risk may in part be due to concomitant exposures. Hayes concludes that the evidence indicates that the hexavalent form of chromium is the primary agent of chromium-induced carcinogenesis. Solubility and other characteristics of chromium compounds may also play a role in determining risk.

\section{STUDIES OF OCCUPATIONAL GROUPS EXPOSED TO CHROMIUM}

Studies of workers in leather tanneries, where exposure is 
also primarily to chromium(III), have shown no lung cancer excess. Pippard et al. ${ }_{52}$ studied the mortality of two groups of British tanners. One group consisted of 573 men who had been employed in preparing leather tanned by vegetable extracts for shoe soles and heels. The other group were 260 male tannery workers who had used chrome tanning to treating leather for the upper parts of shoes. The follow-up extended from 1939 to 1982 . No significant excess of deaths was reported for any of the common sites of cancer in either group of workers. Unfortunately, the number of men in the study was small, and therefore the power of the study to detect a statistically significantly raised mortality was low unless the risk involved was high.

Stern et al. ${ }_{53}$ also studied retrospectively the mortality of a cohort of 9365 chrome leather tannery workers as of 1940 in two tanneries in the United States. Potential hazardous workplace exposure included chromate pigments, nitrosamines, benzidine-based dyestuffs, formaldehyde, leather dust, and aromatic organic solvents. Although the smoking habits of the cohort were unknown, the two tanneries strictly enforced anti-smoking rules. Stern et al. 58 thus argued that the employees probably did not smoke more than the population used for comparison. Mortality from all causes combined was lower than expected in each tannery. Deaths from cancer of each site were also lower than expected when compared either to the US population rates or to local state rates. These results corroborated the Pippard et al. ${ }_{57}$ study that focused specifically on employees of the leather tanning and finishing industry. In discussing the findings of their study, Stern et al. ${ }_{58}$ noted several limitations. Exposure measurements had never been conducted at either tannery. The outcome measure used in the study was mortality, which may not be an adequate indicator of potential work-related health risks. This may be the case for diseases that are treatable, such as bladder cancer. The ascertainment of vital status was only $95 \%$ complete. In some cases, the personnel records may also have been incomplete. A strength of the study was its relatively large size, although naturally the power is dependent on the number of observed deaths for the different causes. Stern et al. ${ }_{58}$ summarized their findings as follows: "although this study revealed some elevated risks for certain causes of death among tannery workers, no significantly increased risks were noted for any cause of death thought a priori to be occupationally related. Several limitations of this study, however, are discussed which may have accounted for our negative findings. Considering the limitations of this study, it would be improper to conclude that employment in the leather, tanning, and finishing industry presents no occupational health risks."

In an update of the previous study, Stern ${ }_{54}$ (2003) followed up the combined cohort of tannery workers for an additional 11 years, with data on vital status and work histories and 1,153 new deaths. No primary cause of death was shown to be significantly elevated, with the exception of lung cancer at one tannery, when state death rates were used as the standard (SMR $=130,95 \%$ Confidence Interval, CI 108-156). Stern concluded that although some studies have shown elevated risks for various site-specific causes of cancer, the sites in excess have not been consistent between studies. The differences may have been due to distinct processes used by the tanneries, resulting in varying levels and different types of exposures.

Seniori Costantini et al. ${ }_{55}$ studied the mortality of 2,926 male workers at the tanneries in the "leather" area of Tuscany in Italy. They were concerned with definite or suspected carcinogens used in the tanning cycle, in particular chromate pigments, benzidine based dyes, formaldehyde, and organic solvents. They found no excess of cancers of all sites, but slight, statistically non-significant, increases were shown in deaths from cancers of the lung $(\mathrm{SMR}=131, \mathrm{CI}$ 88 -182), bladder (SMR = 150, CI 48-349), kidney $(\mathrm{SMR}=$ 323, CI 86-827), pancreas (SMR = 146, CI 39-379), and leukemia (SMR $=164$, CI 53-383). Because of the exposure to multiple carcinogens and the relatively short period of exposure, the results from this follow-up were nevertheless inconclusive.

Seniori Costantini et al. ${ }_{56}$ reviewed epidemiologic studies on occupational cancer risk in the tanning, leather and shoe industries. The high risk of nasal cancer related to exposure to leather dust, which had already been demonstrated in the beginning of the 1970s, was confirmed in more recent studies conducted in the $\mathrm{UK}_{57}(\mathrm{SMR}=536, \mathrm{CI} 257-985)$ and Italy ${ }_{58}(\mathrm{SMR}=622,95 \%$ CI 376-976; Odds Ratio $=$ 8.1, 95\% CI 2.0-33.5). Seniori Costantini et al. (1990) noted that an excess of leukemia among shoe workers had been confirmed in two cohort studies carried out in Italy (Paci, Uitti eta al., 1989, SMR 400, 95\% CI 146-870) and the UK (Pippard and Acheson, 1985, SMR = 215, CI 86-443). In the shoe making industry, workers are exposed to leather dyes and glues which contain solvents, including benzene in the past. In addition to the evident increase in these two cancers, Seniori Costantini et al. ${ }_{61}$ pointed out an excess of cancer of other sites among leather and shoe workers, in particular 
bladder cancer. Another interesting result was the excess of lung cancer among tannery workers. Seniori Constantine et al. ${ }_{61}$ concluded that this evidence was unanimous in the studies carried out in Italy, but was not supported by the majority of studies conducted in other countries. Finally, the authors considered it important to carry out a multicenter study in Italy, with particular attention paid to the definition of occupational exposures to carcinogens.

Mikoczy et al. ${ }_{60}$ studied the incidence of cancer among Swedish leather tannerery workers. In a cohort of 2,026 workers, they found a significantly increased incidence of soft tissue sarcomas (SMR = 427, CI 139-997), based on only five cases. Non- significant excesses were also found in multiple myelomas (SMR $=254$, CI 93-553) and sinonasal cancer (SMR = 377, CI 46-136). However, the researchers concluded that the plausible cause of the increased risk of soft tissue sarcomas was chlorophenols that had been present in all the three plants investigated.

Hayes et al. ${ }_{61}$ carried out a study of mortality among 1,879 male workers employed in a New Jersey chromium pigment factory (exposure to lead and zinc chromates), with followup from 1940 to 1982 . The total number of years of employment in the factory and the total number of years of exposure to chromate dusts were both statistically significantly associated with an increased risk for lung cancer. The excess risk for lung cancer associated with duration of exposure to chromate dusts was, however, only clearly apparent for subjects followed for 30 years or more after initial employment. For this group, the SMRs were 81, 139, 201, and 321 for the subjects with 0 years, less than 1 year, 1-9 years, and 10+ years of exposure. Moreover, Hayes et al. ${ }_{66}$ could not evaluate the effects of exposure to zinc and lead chromate separately.

Chromium(III) and chromium(VI) chemicals are used for chrome plating. However, it needs to be stressed that trivalent chromium plating is relatively new around 20 years old and even now it is not widely used throughout the world. Hence all exposures in the chromium plating industry were certain to have been to hexavalent chromium only. This fact should be taken into account when drawing conclusions on the epidemiologic studies. Moreover, although solutions of trivalent chromium salts can be used successfully for decorative plating requirements, their use generally is still very minor. Chromium platers exposed to soluble chromium (chromium(VI)) oxide $\left(\mathrm{CrO}_{3}\right)$ have shown evidence of an increased risk for lung cancer. ${ }_{62}{ }_{63}{ }_{64}$ A British study ${ }_{19}$ found an increased risk ratio with time since first exposure, and showed that the excess was not due to confounding exposure to nickel. In an update of the British study, ${ }_{65}$ a cohort of 1090 chrome platers exposed to chromium (chromium(VI)) acid were followed-up for the period 1972-97. Significantly increased mortality from lung cancer was observed. Confident interpretation is not possible but occupational exposure to hexavalent chromium may well have been involved. However, a clear distinction between the relative carcinogenicity of chromium compounds of different oxidation states or solubilities is difficult to achieve.

Chromium metal production workers are exposed to metallic and chromium(III) compounds (e.g. chromium oxide $\mathrm{Cr}_{2} \mathrm{O}_{3}$ and chromite ore $\left(\mathrm{CrFeO}_{4}\right)$ are very insoluble), but possibly also to some chromium(VI) compounds, benzo(a)pyrene, and asbestos. The following three studies referred below are associated with the production of ferrochromium or stainless steel, or both. In a Swedish study, ${ }_{66}$ no excess of respiratory cancer was found, while a study in Norway ${ }_{67}$ showed an excess only compared with lung cancer rates in the local population, but the results were inconclusive due to coexposure with chromium(VI). In a French study, ${ }_{68}{ }_{69}$ no evidence was found of the carcinogenicity of chromium. A US study ${ }_{70}$ relates to the manufacture of chromium chemicals, and there were significant exposures to both trivalent an hexavalent chromium. According to the conclusion of the study, hexavalent chromium was related with an excess risk of lung cancer, whereas trivalent chromium was not. The results of these four studies do not support the earlier suggestion by Mancuso ${ }_{71}$ that chromium(III) compounds are potentially as carcinogenic as chromates. This apparent discrepancy calls for a more detailed examination of these studies, which is given below.

The US study ${ }_{41},{ }_{76},{ }_{72}$ followed up successive cohorts by year of hire (1931-1937) at the same chromate manufacturing plant through 1993. There were no smoking data available. An exposure index was formed as a weighted average of exposure to the types of chromium (based on measured atmospheric concentrations) in the departments where the worker had been engaged during his work history. However, the industrial hygiene measurements were not concurrent with work history, because measurements made in 1949 were used to estimate exposure of workers who began employment in 1931-1937. Exposure group and age for total chromium exposure but not for hexavalent or trivalent exposure presented a lung cancer risk. Lung cancer death rates increased by gradient level of exposure to trivalent and 
hexavalent chromium. To investigate whether the relationship was due to one form of chromium compound, either chromium(III) or chromium(VI), the age-adjusted death rates of the two compounds were cross-classified by the level of the total chromium. Mancuso therefore concluded that all forms of chromium are carcinogenic. Previously, the IARC ${ }_{1}$ working group had noted that the three classes of exposure were highly correlated, and that the risks of exposure to trivalent and hexavalent chromium could not be distinguished form each other. Although Mancuso $_{77},{ }^{\text {p. } 138}$ stated that his tables "clearly establish that the finding of lung cancer cannot be attributed solely to one form of chromium, the soluble (hexavalent) chromium. The carcinogenic risk for lung cancer includes the insoluble (trivalent) form of chromium.", he did not present any kind of statistical analysis to verify his conclusion. In particular, Mancuso made no effort to examine the effect of the exposures in a multiple regression. On inspection of the exposure distributions of chromium(III) in Table VIII and chromium(VI) in Table XI presented by Mancuso, ${ }_{77}$ it is evident that they are highly correlated. Even an appropriate statistical analysis (i.e. multiple regression) might not be able to discriminate the separate effects of these compounds when collinearity is high.

The Swedish study ${ }_{70}$ was carefully designed and analyzed but it is not without limitations as all epidemiologic (nonexperimental) studies are. The study base was defined as all males employed for at least 1 year between 1930 and 1975 at a Swedish plant producing ferrochromium alloys from chromite ore. The information on the levels of chromium exposure in different parts of the ferrochromium industry was based on approximations, and no measured data existed for the etiologically relevant periods when a possible occupational cancer could have been induced. Workers were classified by length of service and place of work in the plant. Cancer deaths were obtained from the national Central Bureau of Statistics. Cancer incidences were collected from the Cancer Registry. Expected deaths and cancer cases were computed using a life table method. The choice of 15 years as a latent period from the start of employment for all cancer sites in this study must be considered as approximate. In the Swedish study, no data on smoking habits of the employed workers were available. As the authors themselves concluded, the study could not show an increased death rate or an increase in the incidence of cancer in the workers of the ferrochromium plant. Thus it is reasonable to suspect that the risk of developing respiratory tumors after inhaling chromium(III) compounds is considerably lower than the risk of developing such tumors after exposure to chromates.

The Norwegian study ${ }_{73}$ included all male workers employed at a ferrochromium and ferrosilicon furnace for at least 1 year from 1928 onwards, allowing for a latency period by excluding those who entered work after 1960. Observed and expected cancer cases and deaths were derived from national data on incidence and deaths. Although a significant excess risk was identified for cancer incidence in the ferrochromium subgroup when using all non-ferrochromium workers as a reference group (Standardized Incidence Rate Ratio 3.0, 99\% CI 1.1-6.4), measurements conducted in the plant in 1975 indicated the presence of both chromium(III) and chromium(VI) in the working atmosphere. Hence, the question of whether exposure to chromium(III) is carcinogenic in humans could not be answered.

Svensson et al. ${ }_{74}$ examined a cohort of 1,164 male workers in an industry that produced articles from stainless steel. Measurements of the total dust in the workroom air showed the presence of chromium during grinding and polishing. They found statistically increased morbidity from colorectal cancer $(\mathrm{SMR}=283, \mathrm{CI} 147-519$, in the period 1958-1983), with at lest 5 years exposure and allowing for a 20-year latency period. Swenson et al. 79 were not able to conclude whether the cause was the grinding material, grinding agents, stainless steel, or some other factor. The results did not indicate that dust from stainless steel induces lung cancer.

In a French study ${ }_{75}$ among workers engaged in the production of stainless steel and metallic alloys, lung cancer mortality was in excess, but the link was stronger for polycyclic aromatic hydrocarbons than for chromium exposure. Another French study ${ }_{76}$ aimed at assessing potential risk of lung cancer related to occupational exposure that might have occurred when producing stainless steel. The process involved exposure to multiple carcinogens, i.e. chromium, nickel, silica, asbestos, and polycyclic aromatic hydrocarbons. No significant excess of lung cancer was found in the manufacture of ferroalloys and in the melting and casting of stainless steel, whereas a significant excess (SMR = 334, CI 119-705) was observed among workers with more than 30 years of employment in the foundry area. However, Moulin et al. ${ }_{81}$ could not point out a specific causal factor because of the many simultaneously occurring exposures in the industry.

In an update of the previous French studies, ${ }_{77}$ the risk of lung cancer due to exposure to metals, for example, 
chromium and its compounds was investigated in a cohort follow-up of 4900 workers from 1968 to 1992. Occupational exposure to chromium was assessed through the complete job histories of the workers and a special job-exposure matrix. The manufacture of ferroalloys and stainless steel generates a complex mixture of particles, fumes, and chemicals, among which nickel, trivalent and hexavalent chromium are present. The quantitative exposure variates included in the analysis were increasing exposure levels, duration of exposure, frequency (un)weighted cumulative dose. All exposures were included in the analysis, assuming an induction period (i.e. time span for which the illness remains latent) of 10 years for lung cancer. All potential confounders, which in a univariate analysis seemed to have an effect, that is, smoking and known occupational exposures, were adjusted for using a conditional logistic regression analysis. The analysis was restricted to workers whose smoking habits were known. In a case-referent study nested in the cohort, no excess mortality from lung cancer was observed. Unexpectedly asbestos exposure showed no relation to lung cancer. This finding could be explained by the fact that in a steel factory, where asbestos is used only as an insulation material, the exposure level to asbestos may be lower than in other types of industrial manufacturing of products containing asbestos. The authors concluded that the study failed to demonstrate any relationship between lung cancer and exposure to chromium (predominantly chromium(III)) or its compounds.

Gibb et al. ${ }_{78}$ studied whether chromium(III) exposure, like chromium(VI), is associated with an excess lung cancer risk in chromate production workers. They followed a cohort of 2,357 workers first employed between 1950 and 1974 at a chromate production plant until December 31, 1992. Work histories of cohort members were compiled from the beginning of employment through 1985, the year the plant closed. Annual average exposure estimates, based on historical exposure measurements for each job title in the plant for the years 1950-1985, were made to construct a jobexposure matrix. These exposure estimates were used to calculate the cumulative chromium(VI) exposure of each member of the study population. Following closure of the plant, settled dust samples were collected and analyzed for hexavalent and trivalent chromium. The trivalent/hexavalent concentration ratios in each plant area were combined with historic air-sampling data to estimate cumulative chromium(III) exposure for each individual in the study cohort. Smoking status (yes/no) as of the beginning of employment and clinical signs of potential chromium irritation were identified from company records. Observedto-expected mortality ratios were calculated for various causes of death for whites, nonwhites, and the total cohort. Expected numbers of deaths were calculated using agecalendar, as well as race-specific U.S. mortality rates and the State of Maryland rates. Cumulative exposure was counted for each person at a given age. An induction period of 5 years was assumed for the illnesses.

Proportional hazards models using age as the time variate, cumulative exposure as a time-varying covariate, and smoking as a confounding covariate were applied to assess the relationship between cumulative chromium exposure and lung cancer mortality risk. When one exposure variate at a time was included in the model, cumulative chromium(VI) exposure and cumulative chromium(III) exposure were found to have separately almost equivalent, statistically significant risk (or hazard) ratios for each 10-fold increase in cumulative exposure: 1.38 (CI 1.20 - 1.60) and 1.32 (CI 1.15 - 1.51), respectively. Despite the very strong correlation between the log of cumulative chromium(VI) exposure and the log chromium(III) exposure (correlation coefficient = 0.95), Gibb et al. ${ }_{83}$ made an attempt to analyze the adjusted effects of exposure to the two types of chromium compounds. The inclusion of both exposure variates as risk factors in the same model resulted in cumulative chromium(VI) exposure remaining statistically significant, although at a lower significance level, and the risk ratio attained a higher value, 1.66 (confidence interval was not given but it was presumably wide). On the other hand, the association between cumulative chromium(III) exposure and lung cancer risk did not retain its statistical significance, and apparently the risk ratio was less than unity, 0.84 (correcting for the given erroneous value of 0.17 ).

A likely explanation for these results is that chromium(III) acts as a proxy variate for chromium(VI). In this case, the estimated risk ratios will change drastically from the ones obtained from separate analyses, and the confidence intervals for the risk ratios will become very wide. Such changes are to be anticipated whenever the values of the regression variates are highly correlated, as was the case in the Gibb et al. ${ }_{83}$ study. The phenomenon is well known in statistics and is termed collinearity. ${ }_{79}$ In this situation, the predictor variates are so strongly correlated that it is difficult or impossible to come up with reliable estimates of the actual risks.

The multivariate regression analysis performed by Gibb et 
al. ${ }_{83}$ does not exclude the theoretical possibility that trivalent chromium could be a causal risk factor. However, when two highly correlated variates are entered jointly into a model, the risk factor, which has the stronger association of the two with the disease risk, remains statistically significant, whereas the other risk factor apparently loses its significance, although it would have a causal relation with the disease risk. Therefore an unambiguous answer is simply not possible in the presence of collinearity. ${ }_{80}$ Whether trivalent chromium is not carcinogenic,or whether its carcinogenic effect is masked by the much stronger effect of hexavalent chromium, is still to be determined.

Compared with the study by Mancuso, ${ }_{77}$ the study by Gibb et al. ${ }_{83}$ had a 5.5 times larger study base, 1.8 times as many lung cancer cases, and had smoking information for $93 \%$ of the cohort versus $0 \%$ in the comparison study cohort. Many of the exposure estimates in the Gibb et al. ${ }_{83}$ study were from concurrent measurements with the work history (a portion were from models using contemporary data) and were ambient measures of hexavalent chromium directly not derived from other measures. The Mancuso ${ }_{77}$ study expressed the atmospheric concentrations of chromium in terms of elemental chromium (to avoid the inference of implicating any specific compounds in relation to cancer!), and used measurements that were not concurrent with work history. As already noted, the Gibb et al. (2000) study made an attempt to assess the separate risk estimates of chromium(III) and chromium(VI) for carcinogenicity, whereas in the Mancuso ${ }_{77}$ study no such effort was made. The Mancuso ${ }_{77}$ study presented an argument using autopsy results indicating that trivalent chromium is carcinogenic as pointed out by Gibb et al., ${ }_{83}$ although again, the results may be confounded by the presence of hexavalent chromium. The high correlation between the two chromium species also rendered the otherwise well-conducted study by Gibb et al. 83 inconclusive.

A large Canadian case-referent study on risk factors for cancer in the workplace evaluated a large number of substances including chromium compounds, chromium dust, chromium fumes and chromium(VI) compounds. 81 Unfortunately, in this methodologically excellent study trivalent chromium was not coded separately. Therefore, the results did not include risk estimates specifically for chromium(III).

\section{NASAL CANCER AND EXPOSURE TO}

\section{CHROMIUM}

In addition to the epidemiologic studies on nasal and sinonasal cancer reported in the context of the IARC evaluation, three studies can be mentioned. A joint DanishFinnish-Swedish case-referent study on nasal and sinonasal cancers collected from the national cancer registries or from the hospitals showed a significant association with exposure to chromium. ${ }_{82}$ The category welding, flame cutting and soldering, which represented mixed exposure, was associated with nasal carcinomas. Stainless steel welding involves the greatest exposure to hexavalent chromium. Findings from two epidemiological studies (a case-referent study and a case series report) conducted in Italy indicated a significantly increase risk of sinonasal cancer associated with shoe-making, shoe-repairing and leather tanning occupations, where exposure is primarily to chromium(III). See also other studies regarding other potential exposures. 83 Chromium salts and natural tannins have been indicated as possible etiological agents. A cohort study of former chromium workers in the U.S. found an increased risk of nasal cavity/sinus cancer in association with hexavalent chromium exposure among chromium compound production workers. ${ }_{84}$ Epidemiological studies of the UK chromium chemical manufacturing industry also show an elevated risk of sinonasal cancer.

\section{POSSIBLE CARCINOGENIC MECHANISMS}

Hypotheses about the carcinogenicity of specific chromium compounds generally relate to their solubility in body fluids, their behavior within the body and the ability of relevant chromium species to enter target cells and initiate the cancer process. These hypotheses have, almost unexceptionally, been produced as a result of toxicologic, not epidemiologic, investigations. But, results of epidemiologic studies are most convincing when supplementary information on biological processes that support the observed association is available. Thus we should pay more attention to the biological plausibility, and attempt to integrate the epidemiologic findings with those emanating from the laboratory. The mechanistic and epidemiologic approaches should be viewed as complementary, rather than competing.

The hexavalent form is generally a much more potent mutagen than the trivalent one. Several studies have been conducted on the possible carcinogenic mechanisms of $\mathrm{Cr}[\mathrm{III}]$. Various hexavalent chromium-bearing substances are capable of inducing administration-site tumors. ${ }_{40}$ Trivalent chromium compounds and materials and chromite ore have been negative in animal carcinogenicity assays, 
whereas studies of chromium metal have been largely inadequate. ${ }_{40}$ Intracellular reduction of $\mathrm{Cr}[\mathrm{III}]$ or $\mathrm{Cr}[\mathrm{VI}]$ and the reaction of $\mathrm{Cr}[\mathrm{III}]$ with DNA may be the critical events in chromium carcinogenesis. For example, Singh et al. 85 have suggested that $\mathrm{Cr}[\mathrm{VI}]$ is the active form which penetrates into the cell, but the final mutagenic and cytogenetic effects are due to its intranuclear reduction to $\mathrm{Cr}[\mathrm{III}]$. In the following, reference is made to some of these mechanisms as summarized in the literature. Cohen et al. 86 provide a comprehensive overview (with 340 references) of mechanisms of chromium carcinogenicity and toxicity. A more recent review is given by De Flora. 87

Friedman et al. ${ }_{88}$ studied the mechanism of chromosomal aberrations by $\mathrm{Cr}[\mathrm{III}]$ compounds in human lymphocytes. They examined the possible clastogenic effects of trivalent chromium chloride $\left(\mathrm{CrCl}_{3}\right)$. $\mathrm{Cr}$ [III] induced chromosomal aberrations in phytohemagglutinin-stimulated human lymphocytes. This activity, however, was suppressed by antioxidants. The authors suggested that $\mathrm{Cr}[\mathrm{III}]$ might possess tumor-promoter-like properties.

$\mathrm{Cr}[\mathrm{VI}]$ compounds are reduced intracellularly to DNA- and protein-reactive $\mathrm{Cr}[\mathrm{III}]$ species. Snow and $\mathrm{Xu}_{89}$ examined the role of $\mathrm{Cr}[\mathrm{III}]$ ions in chromium-induced genotoxicity by investigating the effects of $\mathrm{Cr}[\mathrm{III}]$ binding on DNA replication and polymerase processivity in vitro. Chromium ions were found to bind slowly and in a dose-dependent manner to DNA. Micromolar concentrations of free chromium inhibited DNA replication, but if the unbound chromium was removed by gel filtration, the rate of DNA replication by polymerase I (Klenow fragment) on the chromium-bound template was greater than 6-fold relative to the control. This increase was paralleled by as much as a 4fold increase in processivity and a 2 -fold decrease in replication fidelity. These effects were optimal when very low concentrations of chromium ions were bound to the DNA. Increased concentrations of chromium led to the production of DNA-DNA cross-links and inhibition of polymerase activity. The results of Snow and $\mathrm{Xu}{ }^{94}$ suggest that low levels of DNA-bound $\mathrm{Cr}[\mathrm{III}]$ ions may contribute to chromium mutagenesis and carcinogenesis by altering the kinetics and fidelity of DNA replication.

Ding et al. ${ }_{90}$ have reviewed some of the recent findings concerning key molecular events elicited by minerals and metals. They pointed out that reactive oxygen species have been implicated in the pathogenesis of cancer. Inhalation of inorganic minerals such as asbestos and crystalline silica, and metals such as arsenic, beryllium, chromium, nickel, and vanadium, may promote directly and indirectly enhanced generation of reactive oxygen species at a persistent level in agreement with chronic inflammation. Generation of perpetual reactive oxygen species can cause specific molecular changes resulting in activation or proliferation, differentiation, and eventually carcinogenesis. Ding et al. noted that the mechanisms involved in the signal transduction leading to these processes include genotoxicity, DNA damage, lipid peroxidation, activation of transcription factors activator protein-1 or nuclear factor kappa B, and p53 or k-ras gene alterations. These studies point out that reactive ogygen species signaling is critical for the responses of cytokines, growth factors, and activation or inactivation of transcription factors that promote carcinogenesis.

Snow $_{91}$ studied the omplicated metabolism of chromium and its unknown mechanism of mutagenesis. The following is a direct citation from the abstract of their study.

"Chromium[VI] is taken up by cells as the chromate anion and is reduced intracellularly via reactive intermediates to stable $\mathrm{Cr}[\mathrm{III}]$ species. Chromium[III] forms tight complexes with biological ligands, such as DNA and proteins, which are slow to exchange. In vitro, $\mathrm{CrCl}_{3} \cdot 6 \mathrm{H}_{2} \mathrm{O}$ primarily interacts with DNA to form outer shell charge complexes with the DNA phosphates. However, at micromolar concentrations, the $\mathrm{Cr}[\mathrm{III}]$ binds to a low number of saturable tight binding sites on single-stranded M13 DNA. Additional chromium interacts in a nonspecific manner with the DNA and can form intermolecular DNA cross-links. Although high concentrations of $\mathrm{Cr}[\mathrm{III}]$ inhibit DNA replication, micromolar concentrations of $\mathrm{Cr}[\mathrm{III}]$ can substitute for $\mathrm{Mg}^{2+}$, weakly activate the Klenow fragment of E.coli DNA polymerase I (Pol 1-KF), and act as an enhancer of nucleotide incorporation. Alterations in enzyme kinetics induced by $\mathrm{Cr}[\mathrm{III}]$ increase DNA polymerase processivity and the rate of polymerase bypass of DNA lesions. This results in an increased rate of spontaneous mutagenesis during DNA replication both in vitro and in vivo." The results of Snow ${ }^{96}$ indicate that $\mathrm{Cr}[\mathrm{III}]$ may contribute to chromate-induced mutagenesis and may be a factor in the initiation of chromium carcinogenesis.

Hexavalent chromium primarily enters cells and undergoes metabolic reduction. However, the ultimate trivalent oxidation state of chromium predominates within the cell. Singh and Snow ${ }_{92}$ studied how $\mathrm{Cr}[\mathrm{III}]$, in the presence of physiological concentrations of magnesium, affects the kinetic parameters of steady state DNA synthesis in vitro 
across site-specific O6-methylguanine residues by DNA polymerase beta (pol beta). They showed that $\mathrm{Cr}$ [III] decreases the fidelity of DNA synthesis. They concluded that "Both the enhanced activity and the mutagenic lesion bypass in the presence of $\mathrm{Cr}$ (III) may be associated with $\mathrm{Cr}$ (III)-dependent stimulation of pol beta binding to DNA as reported here. This study shows some of the mechanisms by which mutagenic chromium affects DNA synthesis."

\section{OVERALL ASSESSMENT OF CARCINOGENICITY}

The evaluations of the potential carcinogenicity of trivalent chromium and metallic chromium by international and national agencies and individual scientists are unanimous in that the evidence of carcinogenicity is inadequate in humans. For some occupational sources of chromium exposure (e.g. ferrochromium industry and manufacture of chrome pigments) and for some occupations (e.g. leather tannery workers and chromium platers) increased risks have been observed, but almost invariably in the epidemiologic studies the available data do not permit discrimination between the simultaneous exposure to trivalent chromium and hexavalent chromium. Although the chromium compound that increases the risk of lung cancer and sinonasal cancer has yet to be identified, there is fairly general agreement that hexavalent species are responsible for these diseases, and that the trivalent and metallic species are not. For cancers other than those of the lungs and sinonasal cavity, no consistent pattern of cancer risk has been demonstrated in workers exposed to chromium compounds.

\section{ACKNOWLEDGMENTS}

I wish to thank Kirsti Husgafvel-Pursiainen, Timo

Kauppinen, Grant Darrie, and Tuula Nurminen for their valuable comments. The English language revision I owe to Terttu Kaustia.

\section{References}

1. International Agency for Research on Cancer (IARC). IARC monographs on the evaluation of carcinogenic risks to humans, volume 49. Chromium, nickel and welding. Lyon, France: World Health Organization, IARC, 1990.

2. ATSDR. Toxicological profile of chromium. Atlanta, Georgia: U.S. Department of Health and Human Services, Public health Service, Agency for Toxic Substances and Disease Registry (ATSDR), 2000.

3. CEPA. Priority Substances List Assessment Report:

Chromium and its Compounds. Ottawa, Ontario:

Government of Canada, Environment Canada, Health Canada. Canadian Environmental protection Act (CEPA), 1994.

4. US EPA. Toxicological review of trivalent chromium. United States Environmental Protection Agency (US EPA), 1998. Available online at http://www.epa.gov/iris.
5. US NTP. Report on Carcinogens, Tenth Edition; U.S. Department of Health and Human Services, Public Health Service, National Toxicology Program, 2002.

6. IARC. IARC monographs on the evaluation of carcinogenic risks to humans, volume 47 . Some organic solvents, resin monomers and related compounds, pigments and occupational exposures in paint manufacture and painting. Lyon, France: World Health Organization, International Agency for Research on Cancer (IARC), 1989. 7. IARC. Overall evaluations of Carcinogenicity: An updating of IARC monographs, volumes 1 to 42. (Leather tanning and processing, p .236.) Lyon, France: World Health Organization, International Agency for Research on Cancer (IARC), 1987.

8. Korallus U, Ulm K, Steinmann-Steiner-Haldenstaett W. Bronchial carcinoma mortality in the German chromate producing industry: the effects of process modification. Int Arch Occup Environ Health 1993;65:171-8.

9. De Marco R, Bernardinelli L, Mangione MP. Rischio di morte per tumore dell' apparato respiratorio in lavoatori addetti alla produzione di cromati. Med Lav 1988;79:368-76.

10. Satoh K, Fukuda Y, Torrii K, Katsuno N. Epidemiological study of workers engaged in the manufacture of chromium compounds. J Occup Med 1981;23:835-8.

11. Alderson MR, Rattan NS, Bidstrup L. Health of workmen in the chromate-producing industry in Britain. Br J Ind Med 1981;38:117-24.

12. Hayes RB, Lilienfeld AM, Snell LM. Mortality in chromium chemical production workers: a prospective study. Int J Epidemiol 1979;8:365-74.

13. Langård S, Andersen A, Gylseth B. Incidence of cancer among ferrochromium and ferrosilicon workers. Br J Ind Med 1980;37:114-20.

14. Axelsson G, Rylander R, Schmidt A. Mortality and incidence of tumours among ferrochromium workers. Br J Ind Med 1980;37:121-7.

15. Pokrovskaya LV, Shabynina NK. Carcinogeneous hazard in the production of chromium ferroalloys (in

Russian, abstract in English). Gig Tr Prof Zabol 1975;10:23-26.

16. Alderson MR, Rattan NS, Bidstrup L. (1981) Health of workmen in the chromate-producing industry in Britain. Br J Ind Med 1981;38:117-24.

17. Enterline PE. Respiratory cancer among chromate workers. J Occup Med 1974;16:523-6.

18. Langård S, Vigander T. Occurrence of lung cancer in workers producing chromium pigments. Br J Ind Med 1983;40:71-4.

19. Sorahan T, Burges DCL, Waterhouse JAH. A mortality study of nickel/chromium platers. Br J Ind Med 1987;44:250-8.

20. Enterline PE. Respiratory cancer among chromate workers. J Occup Med 1974;16:523-6.

21. IARC. IARC monographs on the evaluation of carcinogenic risks to humans, volume 25 . Wood, leather and some associated industries. Lyon, France: World Health Organization, International Agency for Research on Cancer (IARC), 1981.

22. Acheson ED, Pippard EC. Kidney cancer among leather workers. Lancet 1984 Mar 10;1(8376):563.

23. Pippard EC, Acheson ED, Winter PD. Mortality of tanners. Br J Ind Med1985; 42: 285-7.

24. Edling C, Kling H, Flodin U, Axelson O. (1986) Cancer mortality among leather tanners. Br. J Ind. Med

1986;43:494-6.

25. Puntoni R, Valerio A, Cresta E, Filiberti R, Bonassi S, 
Vercelli M. Mortality study in a tannery (Ital.) Med Lav 1984;75: 471-7.

26. Coggon D, Pannett B, Osmond C, Acheson ED. A survey of cancer and occupation in young and middle aged men. I. Cancers of the respiratory tract. Br J Ind Med 1986;43:332-8.

27. Garabrant DH, Wegman DH. Cancer mortality among shoe and leather workers in Massachusetts. Am J Ind Med 1984;5:303-14.

28. Sweeney MH, Walrath J, Waxweiler RJ. Mortality among retired fur workers. Dyers, dressers (tanners) and service workers. Scand. J. Work Environ. Health 1985;11: 257-64.

29. Cartwright RA, Boyko RW. (1984) Kidney cancer among leather workers. Lancet, 1984 Apr 14;1(8381):850-1. 30. Morrison AS, Ahlbom A, Verhoek WG, Aoki K, Leck I, Ohno Y, Obata K. Occupation and bladder cancer in Boston, USA, Manchester, UK, and Nagoya, Japan J Epidemiol Commun. Health 1985;39:294-300.

31. Malker HR, Malker BK, McLaughlin JK, Blot WJ. (1984). Kidney cancer among leather workers. Lancet 1984 Jan 7;1(8367):56.

32. US EPA. United States Environmental Protection

Agency (US EPA. Toxicological review of trivalent chromium, 1998. Available online at

http://www.epa.gov/iris.

33. US EPA. United States Environmental Protection Agency (US EPA. Health effects assessment for trivalent chromium. Prepared by the Environmental Criteria and Assessment Office, Cincinnati, Ohio, for the Office of Solid Waste and Emergency Response, Washington, D.C., 1984. 34. US EPA. United States Environmental Protection Agency (US EPA). Guidelines for carcinogen risk assessment. Federal Register 1986;51: 33992-4003. 35. US EPA. United States Environmental Protection Agency (US EPA). Proposed guidelines for carcinogen risk assessment. Federal Register 1996;61:17960-8011. 36. US NTP. United States National Toxicology Program (US NTP). The Report on Carcinogens, Tenth Edition. U.S. Department of Health and Human Services, National Institute of Health Public Health Service, National Institute of Environmental Health Sciences, 2002.

(http://ehp.niehs.nih.gov/roc/toc10.html).

37. ACGIF. American Conference of Governmental Industrial Hygienists (ACGIF, 2002). Threshold limit values for chemical and biological exposure indices. Cincinnati, Ohio, 2002.

38. Lees PS. Chromium and disease: review of epidemiologic studies with particular reference to etiologic information provided by measures of exposure. Environ Health Perspect 1991;92: 93-104.

39. Langård S. One hundred years of chromium and cancer: a review of epidemiological evidence and selected case reports. Am J Ind Med 1990;17:189-215.

40. Hayes RB. The carcinogenicity of metals in humans.

Cancer Causes and Control 1997;8:371-85.

41. Hayes RB, Lilienfeld AM, Snell LM. Mortality in chromium chemical production workers: a prospectic've study. Int J Epidemiol 1979;8:365-74.

42. Ohsaki Y, Abe S, Kimura K, Tsuneta Y, Mikami H,

Murao M. Lung cancer in Japanese chromate workers.

Thorax 1978;33:372-74.

43. Davies JM, Easton DF, Bidstrup PL. Mortality from respiratory cancer and other causes in United Kingdom chromate production workers. Br J Ind Med 1991;48:299-313.

44. Sheffet A, Thind I, Miller AM, Louria DB. Cancer mortality in a pigment plant utilizing lead and zinc chromates. Arch Environ Health 1982, 37: 44-52.

45. Hayes RB, Sheffet A, Spirtas R. Cancer mortality among a cohort of chromium pigment workers. Am J Ind Med 1989;16:127-33.

46. Davies JM. (1984) Lung cancer mortality among workers making lead chromate and zinc chromate pigments in three English factories. Br J Ind Med 1984;41:158-69. 47. Haguenoer JM, Dubois G, Frimat P, Cantineau A, Lefrancois H, Furon D. Mortality from bronchopulmonary cancer in a zinc- and lead-chromate producing factory (Fr.). In: Prevention of Occupational Cancer, International Symposium, 1981.

48. Frentzel-Beyme R. (1983) Lung cancer mortality of workers employed in chromate pigment factories. A multicentric European epidemiologic study. J Cancer Res Clin Oncol 1983;105:183-8.

49. Kano K, Horikawa M, Utsunomiya T, Tati M, Satoh K, Yanaguchi S. Lung cancer mortality among a cohort of male chromate pigment workers in Japan. Envion Health Perspect 1991;22;16-22.

50. Hayes RB. The carcinogenicity of metals in humans. Cancer Causes and Control 1997;8: 371-85.

51. Hayes RB. Review of occupational epidemiology of chromium chemicals and respiratory cancer. Science of the Total Environment 1998;71:331-9.

52. Pippard EC, Acheson ED, Winter PD. Mortality of tanners. Br J Ind Med 1985;42: 285-7.

53. Stern FB, Beaumont JJ, Halperin WE, Murthy LI, Hills BW, Fajen JM. Mortality of chrome leather tannery workers and chemical exposures in tanneries. Scand J Work Environ Health 1987;13:108-17.

54. Stern FB. Mortality among chrome leather tannery workers: An update. Am J Ind Med 2003;44:197-206. 55. Seniori Costantini A, Paci E, Miligi L, Buiatti A, Martelli C,Lenzi S. Cancer mortality among workers in the Tuscan tanning industry. Br J Ind Med 1989;46:383-8 56. Seniori Costantini A, Merler E, Saracci R. Studi epidemiologici su rischio cancerogeno ed attività lavorativa nell'industria della concia, pelletteria e calzatura.

[Epidemiological studies on occupational cancer risk in the tanning, leather and shoe industries.] La medicina del lavoro 1990;81:184-211.

57. Pippard EC, Acheson ED, Winter PD. Mortality of tanners. Br J Ind Med 1985;42: 285-7.

58. Baldasseroni A, Merler E, Laria R, Faravelli P. Aggiornamento della lista dei casi di tumore delle fossa nasali e stima dell'incidenza tra gli esposti a polvore di cuoio nell'area di Vigevano. Atti del $50^{\circ}$ Congresso Nazionale della Sociatà Italiana de Medicina del Lavoro e Igiene Industriale. Roma, 21-24 ottobre 1987. Bologna: Monduzzi Editore 1987:505-508. Atti del 50 ${ }^{\circ}$ Congresso Nazionale della Sociatà Italiana de Medicina del Lavoro e Igiene Industriale., Roma, 21-24 ottobre 1987. Bologna: Monduzzi Editore, 1987:505-8.

59. Loi AM, Amram DL, Bramanti L, Roselli MG,

Ciacomini G, Simi U, Belli S, Comba P. Nasal cancer and exposure to leather wood and leather dust. A case-control study in Pisa area. J Exp Clin Canc res 1989;8:13-9. 60. Mikoczy Z, Schütz A, Hagmar L. Occup Environ Med 1994;51:530-5.

61. Hayes RB, Sheffet A, Spirtas R. Cancer mortality among a cohort of chromium pigment workers. Am J Ind Med 1989;16:127-33.

62. Royle H. Toxicity of chromic acid in the chromium plating industryEnviron Res 197510:39-53.

63. Franchini I, Magnani F, Mutti A. Mortality experience among chrome plating workers. Initial findings. Scand J Work Environ Health 1983;9: 247-52. 
64. Okubo T, Tsuchiya K. Epidemiological study of chromium platers in Japan. Biol Trace Elem Res 1979;1:35-44.

65. Sorahan T, Harrington M. Lung cancer in Yorkshire chrome platers, 1972-97. Occup Environ Med 2000;57:385-9.

66. Axelsson G, Rylander R, Schmidt A. Mortality and incidence of tumours among ferrochromium workers. Br J Ind Med 1980;37:121-7.

67. Langård S, Andersen A, Ravnestad J, Incidence of cancer among ferrochromium and ferrosilicon workers; an extended observation period. Br J Ind Med 1990;47:14-9. 68. Moulin JJ, Portefaix P, Wild P, Mur JM, Smagghe G, Mantout B. Mortality study among workers producing ferroalloys and stainless steel in France. Br J Ind Med 1990;47:537-43.

69. Moulin JJ, Clavel T, Roy D, Dananche B, Marquis N, Fevotte J, Fontana JM. Risk of lung cancer in workers producing stainless steel and metallic alloys. Int Arch Occup Environ Health 2000;73:171-80.

70. Gibb HJ, Lees PS, Pinsky PF, Rooney BC. Lung cancer among workers in chromium chemical production. Am J Ind Med 2000;38:115-26.

71. Mancuso TF. Consideration of chromium as industrial carcinogen. International Conference on Heavy Metals in the Environment. Toronto, Ontario, Canada, October 27-31, 1975:343-56.

72. Mancuso TF. (1997) Chromium as an industrial carcinogen: Part I. Am J Ind Med 1997;31:129-39.

73. Langård S, Andersen A, Ravnestad J. Incidence of cancer among ferrochromium and ferrosilicon workers; an extended observation period. Br J Ind Med 1990;47:14-9. 74. Svensson BG, Englander V, Ảkesson B, Attewaell E, Skerving S, Möller T. Deaths and tumors among workers grinding stainless steel. Am J Ind Med 1989;15:51-9. 75. Moulin JJ, Portefaix P, Wild P, Mur JM, Smagghe G, Mantout B. (1990) Mortality study among workers producing ferroalloys and stainless steel in France. Br J Ind Med 47: 537-43.

76. Moulin JJ, Wild B, Mantout B, Fournier_Benz M, Mur JM: Mortality from lung cancer and cardiocascular diseases among stainless-steel producing workers. Cancer Causes Control 1993;4:75-81.

77. Moulin JJ, Clavel T, Roy D, Dananche B, Marquis N, Fevotte J, Fontana JM. Risk of lung cancer in workers producing stainless steel and metallic alloys. Int Arch Occup Environ Health 2000;73: 171-80.
78. Gibb HJ, Lees PS, Pinsky PF, Rooney BC. Lung cancer among workers in chromium chemical production. Am J Ind Med 2000;38: 115-26.

79. Breslow NE, Day NE. 1980. Statistical Methods in Cancer Research, Volume 1 ( The analysis of Case-Control Studies. Lyon: International Agency for Research on Cancer, 1980: Section 6.10.

80. Nurminen M. On the carcinogenicity risk assessment of chromium compounds. Am J Industr Med 2004;45:308-9. 81. Siemiatycki J. Risk factors for cancer in the workplace. Boca Raton: CRC Press, 1991.

82. Hernberg S, Westerholm P, Schultz-LarsenK, Degerth R, Kuosma E, Englund A,

Engzell U, Hansen HS, Mutanen P. (1983) Scand J Work

Environ Health 9:315-26.

IARC (1981).

83. Battista G, Comba P, Orsi D, Norpoth K, Maier A. Nasal cancer in leather workers: an occupational disease. J Cancer Res Clin Oncol 1995;121:1-6.

84. Rosenman KD, Stanbury M. Risk of lung cancer among former chromium smelter workers 1996;29:491-500.

85. Singh CB, Sharma A, Talukder G. Effects of chromium on cellular systems in animals. Nucleus 1990;33:84-106.

86. Cohen MD, Kargacin B, Klein CB, Costa M.

Mechanisms of chromium carcinogenicity and toxicity.

Critical Reviews in Toxicology 1993;23:255-81.

87. De Flora S. Threshold mechanisms and site specificity in chromium(VI) carcinogenesis.

Carcinogenesis2000;21:533-41.

88. Friedman J, Shabtai F, Levy LS, Djaldetti M. Chromium chloride induces chromosomal aberrations in human lymphocytes via indirect action. Mutat Res 1987;191: 207-10

89. Snow ET, Xu LS. Chromium(III) bound to DNA templates promotes increased polymerase processivity and decreased fidelity during replication in vitro. Biochemistry 1991;30:11238-45.

90. Ding M, Shi X, Castranova V, Vallyathan V.

Predisposing factors in occupational lung cancer: inorganic minerals and chromium. J Environ Pathol Toxicol Oncol 2000;19:129-38.

91. Snow ET. (1994) Effects of chromium on DNA replication in vitro. Environ Health Perspect 1994;102 Suppl 3:41-4.

92. Singh J, Snow ET. Chromium(III) decreases the fidelity of human DNA polymerase beta. Biochemistry 1998;37:371-8. 


\section{Author Information}

Markku Nurminen, Ph.D.

Adjunct Professor, Finnish Institute of Occupational Health, University of Helsinki 